\title{
HUBUNGAN KOORDINASI MATA TANGAN DENGAN HASIL SHOOTING ATLIT UKM BOLA BASKET STKIP PGRI LUBUKLINGGAU
}

\author{
Wawan Syafutra* \\ Program Studi Pendidikan Jasmani, Kesehatan, dan Rekreasi \\ Jurusan Ilmu Pendidikan \\ STKIP PGRI Lubuklinggau
}

* Corresponding Author. E-mail: wawan@stkippgri-lubuklinggau.ac.id

Receive: 02/02/2020

Accepted: $18 / 02 / 2020$

Published: 03/03/2020

\begin{abstract}
Abstrak
Shooting dalam permainan bola basket adalah keterampilan yang harus dikuasai oleh setiap pemain. Keterampilan ini sangat memberikan hasil nyata di dalam permainan, semakin baik shooting maka akan semakin berpeluang poin yang tercipta. Koordinasi mata dan tangan menjadi salah satu faktor penentu dalam terciptanya shooting yang mampu menghasilkan poin untuk tim. Mengetahui hubungan antara koordinasi mata tangan dengan hasil shooting dalam permainan bola basket adalah tujuan dari penelitian ini. Metode Pendekatan Deskriptif Korelasional digunakan dalam penelitian ini. Teknik pengambilan sampel yang digunakan adalah purposive sampling pada mahasiswa yang mengikuti ukm bola basket di STKIP PGRI Lubuklinggau sebanyak 25 orang. Data yang diambil dengan melakukan tes koordinasi mata tangan dan shooting bola basket. Berdasarkan data hasil penelitian maka disimpulkan bahwa: Terdapat hubungan yang signifikan antara koordinasi mata tangan dengan hasil shooting dalam permainan bola basket, terbukti $p=0.002<0.05$, dengan Koefisien Korelasi 0,587.
\end{abstract}

Kata Kunci :Bola Basket, Koordinasi Mata Tangan, Shooting.

\begin{abstract}
Shooting in a basketball game is a skill that must be mastered by every player. This skill really gives real results in the game, the better the shooting the more chance the points will be created. Eye and hand coordination is one of the determining factors in the creation of shooting which is able to produce points for the team. Knowing the relationship between hand eye coordination and shooting results in basketball is the aim of this study. The descriptive correlational method was used in this study. The sampling technique used was purposive sampling of 25 students participating in basketball basketball at STKIP PGRI Lubuklinggau. Data were taken by conducting hand eye coordination tests and basketball shooting. Based on the research data, it can be concluded that: There is a significant relationship between hand eye coordination and shooting results in basketball, it is proven that $p=$ $0.002<0.05$, with a correlation coefficient of 0.587 .
\end{abstract}

Keywords: Basketball, Hand Eye Coordination, Shooting. 


\section{Pendahuluan}

Olahraga bola basket merupakan salah satu olahraga populer di dunia. Olahraga ini juga sudah berkembang pesat di Indonesia. Terbukti klub-klub basket yang ada di Indonesia, serta banyaknya kompetisi dari tingkat pelajar hingga profesional. Teknik-teknik dasar tentunya harus dikuasai apabila ingin bermain bola basket dengan baik.Teknik dasar permain bola basket yang perlu dikuasai atlet menurut Sodikun (dalam Sucipto, dkk, 2010, p. 29), mengemukakan bahwa, 'Teknik melempar dan menangkap, teknik menggiring bola, teknik menembak, teknik gerakan berporos, teknik lay up shoot, teknik merayah'. Menurut Budiana, D. \& Lubay, L.H. (2013, p. 26-43) mengemukakan bahwa, "Teknik dasar permainan bola basket, yaitu penguasaan bola (ball handling), mengoper dan menangkap bola (passing and catching), memantulkan bola ke lantai (dribbling), dan tembakan (shooting)". Nidhom Khoeron ( 2017, p 39 ) juga mengungkapkan bahwa " Seorang pemain basket harus memiliki skilldan pengetahuan tentang cara memegang, menangkap, dan mengoper bola kepada temannya

Teknik dasar menembak (shooting) menjadi sangat penting dalam permainan bola basket, karena bertujuan dalam membuat angka sebanyak-banyaknya. Teknik dasar ini merupakan teknik penting yang harus dikuasai setiap pemain basket, karena angka yang didapat dari hasil tembakan akan menentukan kalah menangnya suatu tim. Teknik menembak juga mampu menutupi kelemahan dari beberapa teknik lainnya misalnya :dribbling, bertahan, mengoper dan menangkap bola.Berkaitan hal ini, menurut Wissel, H. (2000, p. 43) mengemukakan bahwa, "Shooting adalah keahlian yang sangat penting di dalam olahraga basket. Teknik dasar seperti operan, dribbling, bertahan, dan rebounding berpeluang untuk membuat skor, tetapi tetap saja anda harus mampu melakukan tembakan. Sebetulnya menembak dapat menutupi kelemahan teknik dasar lainnya". Vic Ambler ( 2016, p. 11 ) mengemukakan pula bahwa : Keterampilan terpenting dalam permainan bola basket ialah kemampuan shooting atau menembakan bola kedalam jala keranjang".

Tembakan dalam permainan bola basket ada dua macam yaitu : tembakan lapangan dan tembakan bebas. Tembakan lapangan adalah suatu percobaan memasukkan bola ke keranjang lawan selama permainan berlangsung dan dilakukan oleh setiap pemain dari segala posisi dalam lapangan dengan sesuai aturan yang berlaku. Sedangkan tembakan bebas adalah suatu tembakan yang diberikan oleh wasit kepada pemain karena terjadi suatu pelanggaran yang dilakukan oleh lawan. Jika seorang pemain berhasil mencetak angka maka mendapatkan nilai satu dari tembakan bebas, nilai dua dari tembakan yang dilakukan di dalam setengah lingkaran, nilai tiga dari tembakan yang dilakukan di luar setengah lingkaran. Diungkapkan oleh Nidhom Khoeron bahwa " Sebuah tim akan mendapatkan point apabila berhasil memasukkan bola kedalam keranjang hingga jatuh ke lantai”. Kesimpulan dari hal diatas adalah betapa pentingnya shooting untuk kemenangan sebuah tim.

Pencapaian prestasi yang tinggi tentunya harus didukung oleh beberapa hal antara lain seorang atlet harus memiliki fisik yang bagus. Menurut Imanudin, I. (2008, p. 199) mengemukakan bahwa,"Kondisi fisik adalah faktor terpenting dalam pencapaian prestasi yang tinggi, atlet yang memiliki kondisi fisik yang bagus akan lebih siap dalam menghadapi proses latihan dan juga pertandingan. Salah satu ciri atlet yang memiliki kondisi fisik yang bagus yaitu ada respon yang cepat terhadap rangsangan dari luar, juga akan ada pemulihan yang lebih cepat dari organisme tubuh". 
Koordinasi merupakan salah satu komponen fisik yang berpetran penting dalam setiap cabang olahraga. Koordinasi merupakan kemampuan gerak yang kompleks karena di dalam pelaksanaannya terdiri atas beberapa unsur kondisi fisik yang saling berhubungan sangat erat. Gerakan yang mulus, tepat, dan efisien sharus mampu dikuasai seseoranng dalam melaksanakan koordinasi. Menurut Lutan, dkk. (2000, p. 77), mengemukakan bahwa, "Koordinasi adalah kemampuan untuk melakukan gerakan dengan berbagai tingkat kesukaran dengan cepat dan efisien dan penuh ketepatan. Koordinasi yang baik akan dapat melakukan berbagai gerakangerakan dengan berbagai tingkat kesulitan secara cepat, penuh sasaran dan tentunya efisien dalam gerakannya".

Koordinasi mata tangan berperan sangat penting dalam shooting pada permainan bola basket dikarenakan ketika seseorang melakukan shooting membutuhkan mata untuk melihat posisi ring basket dan tangan untuk melakukan tembakan ke arah ring. Bola akan jatuh tepat kedalam ring basket apabila seseorang mampu melakukan koordinasi mata tangan yang baik. Namun sebaliknya, koordinasi mata tangan yang buruk akan mengakibatkan gerakan menembak akan kaku sehingga bola akan melenceng dari ring basket.

Seorang penembak yang sudah berada di daerah lawan ingin memasukkan bola ke ring dan penembak sangat yakin bahwa bola yang akan dilepaskan dari tangannya akan masuk ke ring. Ternyata bola yang akan dilepaskan oleh penembak melebar dari ring. Disini peneliti mencoba mengkaji apakah seorang penembak yang tidak memasukkan bola itu disebabkan oleh koordinasi mata tangan yang tidak baik atau ada faktor lain yang menyebabkan bola tidak masuk ke ring basket.

Berdasarkan uraian di atas, penelitian ini akan mencoba untuk mengkaji hubungan antara koordinasi mata tangan dengan hasil shooting dala permainan bola basket.

\section{Metode}

Penelitian ini menggunakan metode penelitian kuantitatif, dengan pendekatan deskriptif korelasional. Menurut Sugiyono (2013, p. 14) mengemukakan bahwa,"Metode penelitian kuantitatif dapat diartikan sebagai metode penelitian yang berlandasakan pada filsafat positivisme, digunakan untuk meneliti pada populasi atau sampel tertentu, teknik pengambilan sampel pada umumnya dilakukan secara random, pengumpulan data menggunakan instrumen penelitian, analisis data bersifat kuantitatif atau statistik dengan tujuan untuk menguji hipotesis yang telah ditetapkan.

Penelitian ini adalah penelitian korelatif yang akan menyelidiki ada tidaknya hubungan antara variabel bebas dan variabel terikat. Variabel bebas (X) dalam penelitian ini adalah koordinasi mata tangan dan fleksibilitas pergelangan tangan dan variabel terikat $(\mathrm{Y})$ adalah hasil shooting bola basket.

Populasi dalam penelitian ini adalah mahasiswa yang mengikuti UKM Bola Basket STKIP PGRI Lubuklinggau yang berjumlah 55 orang. Sampel yang digunakan dalam penelitian ini adalah 25 orang mahasiswa yang mengikuti UKM Bola Basket STKIP PGRI Lubuklinggau. Pengambilan sampel dalam penelitian ini menggunakan teknik purposive sampling yaitu teknik pengambilan sampel dengan pertimbangan tertentu. Adapun karakteristik dari sampel tersebut adalah sebagai berikut:

a. Merupakan anggota yang terdaftar di UKM Bola Basket STKIP PGRI Lubuklinggau.

b. Keaktifan dalam kehadiran dan proses latihan.

c. Telah menguasai teknik shooting

d. Mempunyai pengalaman yang cukup baik dalam permainan dan pertandingan bola basket. 
Dari dasar pertimbangan diatas maka peneliti menentukan jumlah mahasiswa yang akan dijadikan sebagai sampel penelitian yaitu sebanyak 25 orang dari populasi yang telah disebutkan yaitu mahasiswa UKM Bola Basket STKIP PGRI Lubuklinggau.

Instrumen penelitian yang digunakan dalam penelitian ini adalah:

1. Tes untuk mengukurkoordinasi mata tangan menggunakan Wall Pass menuurt Nurhasan dan Cholil (2000, p. 101)

a. Tujuan : Untuk mengukur koordinasi mata tangan

b. Alat : Bola basket, stop watch dan dinding tembok

c. Pelaksanaan Tes : Subjek berdiri di belakang garis batas sambil memegang bola basket dengan kedua tangan di depan dada, bila aba-aba ya diberikan, subjek dengan segera melakukan lempar tangkap kedinding selama 15 detik.

d. Skor : Nilai yang diperoleh subjek dihitung beberapa kali melakukan lempar dan tangkap bola selama 15 detik.

2. Tes untuk menembak 2 angka shooting (menembak) tes ini sudah dilakukan oleh Lutfi Adam dengan jarak $350 \mathrm{~cm}$ (dalam Wijaya, A.T, 2010, p. 49)

a. Validitas $\quad: 0,77$

b. Realibilitas : 0,81

c. Tujuan : Untuk mengukur kemampuan hasil tembakan 2 angka

d. Alat :Lapangan permainan bola basket, stop wacth, 5 bola basket, pluit, formulir.

e. Pelaksanaan Tes : Testee diberikan pemanasan terlebih dahulu, setelah melakukan pemanasan testee disuruh melakukan percobaan menembak di daerah 2 angka sebanyak 2 kali, testee diperbolehkan melakukan tembakan di daerah 2 angka dimana saja, asalkan tidak melewati batas daerah yang telah ditentukan, dengan jumlah tembakan sebanyak 5 kali, pada aba-aba siap, testee berdiri pada posisi tembakan dan menghadap ke arah sasaran, pada aba- aba pluit ditiup bola segera ditembakan ke arah sasaran demikian seterusnya hingga testee melakukan tembakan sesuai dengan jumlah pengulanggannya, 1 testee mengawasi masuk tidaknya bola pada bidang sasaran (ring) dan melaporkan hasil jumlah tembakan pada pencatat, 1 testee mencacat hasil tembakan di daerah 2 point dikasih nilai 2 untuk tiap bola yang masuk ke arah sasaran (ring).

\section{Hasil dan Pembahasan}

Berdasarkan hasil penelitian, maka dapat dilihat kategori penilaian dari koordinasi mata tangan dan shooting sebagai berikut:

Tabel 1.Kategori Penilaian Koordinasi Mata Tangan

\begin{tabular}{|c|c|c|}
\hline No & Rentang Skor & Kategori \\
\hline 1 & $15-$ ke atas & Sangat Baik \\
\hline 2 & $13-14$ & Baik \\
\hline 3 & $11-12$ & Cukup \\
\hline 4 & $10-$ ke bawah & Buruk \\
\hline
\end{tabular}

Tabel 2. Kategori Penilaian Tes Shooting

\begin{tabular}{|c|c|c|}
\hline No & Rentang Skor & Kategori \\
\hline 1 & $10-$ ke atas & Sangat Baik \\
\hline 2 & $7-9$ & Baik \\
\hline 3 & $5-6$ & Cukup \\
\hline 4 & $3-4$ & Buruk \\
\hline 5 & $<3$ & Sangat Buruk \\
\hline
\end{tabular}

Berdasarkan hasil perhitungan nilai rata-rata dan standar deviasi untuk koordinasi mata tangan memiliki rata-rata sebesar 12.16 dan standar deviasi sebesar 1.491. Sedangkan untuk hasilshooting sebesar 6.88 dan standar deviasi sebesar 1.833 .

Tabel 3. Deskriptif

\begin{tabular}{|l|c|c|}
\hline \multicolumn{1}{|c|}{$\begin{array}{c}\text { Variabel } \\
\text { Tes }\end{array}$} & Rata-rata & $\begin{array}{c}\text { Standar } \\
\text { Deviasi }\end{array}$ \\
\hline $\begin{array}{l}\text { Koordinasi } \\
\text { Mata Tangan }\end{array}$ & 12.16 & 1.491 \\
\hline $\begin{array}{l}\text { Hasil } \\
\text { Shooting }\end{array}$ & 6.88 & 1.833 \\
\hline
\end{tabular}


Tabel 4 .Deskriptif Skor Koordinasi Mata Tangan

\begin{tabular}{|c|c|c|c|c|}
\hline No & $\begin{array}{c}\text { Rentang } \\
\text { Skor }\end{array}$ & $\begin{array}{c}\text { Katego } \\
\text { ri }\end{array}$ & $\begin{array}{c}\text { Fre } \\
\text { kue } \\
\text { nsi }\end{array}$ & $\begin{array}{c}\text { Persenta } \\
\text { se(\%) }\end{array}$ \\
\hline 1 & $\begin{array}{c}15-\mathrm{ke} \\
\text { atas }\end{array}$ & $\begin{array}{c}\text { Sangat } \\
\text { Baik }\end{array}$ & 3 & $12 \%$ \\
\hline 2 & $13-14$ & Baik & 6 & $24 \%$ \\
\hline 3 & $11-12$ & Cukup & 13 & $52 \%$ \\
\hline 4 & $\begin{array}{c}10-\mathrm{ke} \\
\text { bawah }\end{array}$ & Buruk & 3 & $12 \%$ \\
\hline
\end{tabular}

Tabel 5. Deskriptif Skor Shooting

\begin{tabular}{|c|c|c|c|c|}
\hline No & $\begin{array}{c}\text { Rentang } \\
\text { Skor }\end{array}$ & Kategori & $\begin{array}{c}\text { Fre } \\
\text { kue } \\
\text { nsi }\end{array}$ & $\begin{array}{c}\text { Persent } \\
\text { ase }\end{array}$ \\
\hline 1 & $\begin{array}{c}10-\text { ke } \\
\text { atas }\end{array}$ & $\begin{array}{c}\text { Sangat } \\
\text { Baik }\end{array}$ & 3 & $12 \%$ \\
\hline 2 & $7-9$ & Baik & 9 & $36 \%$ \\
\hline 3 & $5-6$ & Cukup & 9 & $36 \%$ \\
\hline 4 & $3-4$ & Buruk & 4 & $16 \%$ \\
\hline 5 & $<3$ & $\begin{array}{c}\text { Sangat } \\
\text { Buruk }\end{array}$ & - & - \\
\hline
\end{tabular}

Tabel 6. Uji Korelasi

\begin{tabular}{|l|c|c|}
\hline \multicolumn{1}{|c|}{ Korelasi } & $\boldsymbol{\alpha}$ & Sig. \\
\hline $\begin{array}{l}\text { Koordinasi Mata Tangan } \\
\text { dengan Hasil Shooting }\end{array}$ & 0.05 & 0.002 \\
\hline
\end{tabular}

Pada tabel 6 terlihat bahwa untuk pengujian hipotesis penelitian, yaitu :

Pengujian hipotesis, yaitu terdapat hubungan antara koordinasi mata tangan dengan Hasil Shooting. Berdasarkan hasil analisis data di atas nilai sig. 0.002, karena nilai sig. $<0.05$, maka $\mathrm{H}_{0}$ ditolak, artinya terdapat hubungan yang signifikan antara koordinasi mata tangan dengan hasil shooting dalam permainan bola basket.

Tabel 7. Uji Regresi

\begin{tabular}{|l|c|c|}
\hline Variabel & $\begin{array}{c}\text { R } \\
\text { Square }\end{array}$ & $\begin{array}{c}\text { Presentase } \\
\text { Dukungan }\end{array}$ \\
\hline $\begin{array}{l}\text { Koordinasi Mata } \\
\text { Tangan terhadap } \\
\text { Hasil Shooting }\end{array}$ & 0.344 & $34.4 \%$ \\
\hline
\end{tabular}

Berdasarkan hasil analisis penghitungan presentase dukungan koordinasi mata tangan dengan hasil shooting sebesar 0.353 dan memiliki hubungan sebesar $34.4 \%$ dan sisanya sebesar $65.6 \%$ yang dipengaruhi oleh faktor lain.

\section{Simpulan}

Berdasarkan analisis data yang diperoleh dan uraian yang telah dikemukakan, maka kesimpulan yang dapat di ambil dari hasil penelitian sebagai berikut:

1. Terdapat hubungan antara koordinasi mata tangan dengan hasil shooting dalam permainan bola basket. Dapat dilihat pada Pearson Correlation dengan nilai 0.587 dan nilai sig. $0.002<$ 0.05 , ini berarti terdapat hubungan yang signifikan antara koordinasi mata tangan dengan hasil shooting dalam permainan bola basket.

2. Koordinasi mata tangan dengan skor tertinggi adalah 15 dengan jumlah 3 orang $(12 \%)$ berada pada kriteria sangat baik dan skor terendah adalah 10 dengan jumlah 3 orang (12\%) berada pada kriteria buruk. Sedangkan hasil tes shooting yang memiliki criteria sangat baik sebanyak 3 orang (12\%), kriteria buruk sebanyak 4 orang (16\%).

\section{Daftar Pustaka}

[1] Budiana, D. \& Lubay, H.L. (2013). Pembelajaran Permainan Bolabasket. Bandung: Universitas Pendidikan Indonesia.

[2] Imanudin, I. (2008). Ilmu Kepelatihan Olahraga. Bandung: Universitas Pendidikan Indonesia.

[3] Lutan, dkk. (2000). Dasar-Dasar Kepelatihan. Bandung: Departemen Pendidikan Nasional.

[4] Nidhom Khoeron (2017). Buku Pintar Basket. Jakarta:Anugrah

[5] Nurhasan dan Cholil (2000). Modul Tes Dan Pengukuran Keolahragaan. Bandung: Jurusan Pendidikian Kepelatihan, Universitas Pendidikan Indonesia 
[6] Sucipto, dkk. (2010). Permainan Bola Basket. Bandung: Universitas Pendidikan Indonesia.

[7] Sugiyono. (2013). Metode Penelitian Pendidikan. Bandung: Alfabeta.

[8] Vic Ambler. (2015). Petunjuk untuk Pelatih dan Pemain Bola Basket.Bandung: Pionir Jaya

[9] Wijaya, T.A. (2010). Pengaruh Alat Bantu Latihan (HOOP) Dalam Meningkatkan Teknik Dasar Shooting Terhadap Tembakan 2 Dan 3 Angka Pada Atlet Pemula Dalam Permainan Bola Basket. Skripsi, Universitas Pendidikan Indonesia.
[10] Wissel, H (2000). Bola Basket. Jakarta: Raja Grafindo Persada

\section{Profil Penulis}

Penulis dilahirkan 02 Juni 1992 di Kota Lubuklinggau. Penulis mendapatkan gelar sarjana tahun 2014 di Universitas Pendidikan indonesia serta mendapatkan gelar magister pada tahun 2017 di Universitas Pendidikan Indonesia. Penulis sekarang merupakan Dosen Prodi Penjaskesrek STKIP PGRI Lubuklinggau 